\title{
Management in higher education: an overview of public universities practices in the United States
}

\author{
A gestão no ensino superior: uma abordagem das práticas em \\ universidades públicas dos Estados Unidos
}

\section{Resumo}

A gestão no ensino superior é um tema que vem ganhando mais atenção nas últimas décadas devido ao aumento do número de novas faculdades, especialmente nos Estados Unidos da América (EUA). O sistema norte-americano é único e difere da maioria dos países da América Latina principalmente pela descentralização do poder governamental, que pode ter contribuído para um sistema de gestão autônoma e local. Além disso, há uma comunidade estudantil altamente diversificada e multicultural nos EUA. Assim sendo, este trabalho apresenta uma abordagem sobre a gestão do ensino superior norte-americano, bem como alguns desafios e perspectivas dessa. A metodologia foi uma pesquisa documental realizada na web durante os anos de 2015 e 2016 , com o objetivo de contextualizar o ensino básico no cenário preparatório para o ensino superior. Em seguida, uma análise descritiva dos diferentes níveis de ensino superior foi apresentada, avaliando as recomendações e as normativas federais que contribuíram para um sistema classificatório de acreditação acadêmica. Os resultados indicaram que, na ausência de um ministério federal regulamentador como o Ministério da Educação (MEC) no Brasil, rankings e sistemas de acreditação, como o Carnegie, tornam-se muito importantes como indicadores de qualidade. Entre os aspectos exclusivos do ensino superior dos EUA também está a adoção de conselhos universitários compostos por diferentes membros da comunidade acadêmica que contribuem para a tomada de decisões.

Palavras-chave: Acreditação acadêmica. Preparação para a faculdade. Ensino superior. Universidades públicas. Estados Unidos.

Recebido em: 23/01/2017 - Aprovado em: 19/04/2017

http://dx.doi.org/10.5335/rep.v24i2.7413

B.S. in Biological Sciences with specialization in Environmental Education by the Universidade Federal de Santa Maria (2001). M.S. in Education/ Environmental Practices by the Universidade de Passo Fundo (2006). Ph.D. in Horticulture by the Washington State University (2014). Post-doctorate in Biostatistics by the University of Washington (2016). Ed.D(c) in Leadership by the Fundación Universitaria Iberoamericana (2017). Adjunct Professor at OCC in Syracuse, NY, USA. E-mail: elianeb@uw.edu

** B.S. in Environmental Sciences by the Ohio State University (2006). Ph.D. in Biological Systems Engineering by the Washington State University (2013). M.B.A. by the University of Washington (2016). Assistant Director at Cornell University, in Geneva, NY, USA. E-mail: bbodah@wsu.edu 


\title{
Abstract
}

\begin{abstract}
Management in higher education is a topic that has been gaining more attention in the past decades due to the increase of new colleges, especially in the United States. This higher education system is unique and differs from most countries in Latin America. Decentralization of governmental power might have contributed to a more autonomous and place-based management system. In addition, there is a highly diverse and multicultural student community in the US. Our work presents a management in higher education overview in the US as well as some challenges and perspectives in this field. Our approach was a web-based documental research performed during the years of 2015 and 2016, aiming to contextualize the basic education scenario in the North American college preparatory. Next, we conducted a descriptive analysis of the different levels of higher education, evaluating federal normative recommendations that contributed to a classificatory system of accreditation. Overall, our results indicated that in the absence of a federal regulatory ministry such as the MEC in Brazil, ranking and accreditation systems such as the Carnegie system become very important as an indicator of quality. Among the unique aspects of the US higher education is the university council composed by different members of the academic community to help in decision-making processes.
\end{abstract}

Keywords: Academic Accreditation. College Preparation. Higher Education. Public Universities. United States.

\section{Introduction}

Management in the public higher education system in the United States (US) is very unique and differs from most countries in Latin America, especially from Brazil. Decentralization of governmental power might have contributed to a more autonomous and place-based management system. In addition, there is a highly diverse and multicultural student community in the US.

Our work presents a management in higher education overview in the US as well as some challenges and perspectives in this field. Our approach was a web-based documental research performed during the years of 2015 and 2016, aiming to contextualize the basic education in the North American college preparatory scenario. Next, we conducted a descriptive analysis of the different levels of higher education, evaluating federal normative recommendations that contributed to a classificatory system of accreditation.

There are federal initiatives proposed by the US Department of Education (USDE) that aim to provide regulations, negotiated rulemaking, legislation, data reporting, and other policy initiatives related to post-secondary education and federal student financial assistance programs, including the academic competitiveness and national specific, measurable, attainable, realistic and timely (SMART) grant programs. Within the USDE, the Office of Post-secondary Education (OPE) formulates federal post-secondary education policy including policy relating to the federal student financial assistance programs. OPE also collects and disseminates student financial assistance program data as well as data in several key areas relating to post-secondary education. 
Despite federal initiatives, management finds additional support and guidance at the state level. This is due to the fact that each of the 50 states are responsible for developing and implementing their own education policy, some of which differ from federal policy considerably. Such independence creates a diversity of management systems. In this work, we will also illustrate higher education management at the state level using Washington State as a model.

Each institution of higher education also has a great power of decision-making and management strategies. In general, the internal management of US universities and colleges counts on an academic council that contributes actively to the administration and direction of the institution. This academic council is comprised of representatives who hold different positions as administrators, professors, students, and even community member or volunteers.

\section{Basic education and college preparation}

Before considering post-secondary education, students in the United States go through the basic education system that includes pre-school, elementary, middle school, and high school, in a total of about 12 years of studies. Pre-school preparation begins at a young age in pre-kindergarten centers and nurseries. Admission to elementary school is between five to six years of age, with some exceptions. Throughout elementary and middle school, students focus on learning basic subjects and improving necessary life skills. A recent trend is focusing on practical and field classes in the fields of science, technology, engineering, and mathematics (STEM).

During high school, students can develop their own in-depth projects, as well as sign up for advanced placement classes, some of which earn college credit through partnership with local universities. The final year of high school can involve presentations or a final academic project to earn their diploma. High school students who take college classes for credit can apply the courses toward the credit requirements of future undergraduate degrees. Youth and adult education are not formal modalities of teaching offered in the US system. However, alternatives to the completion of high school are offered in several educational centers, aiming to provide students with a rough equivalent to a high school diploma, a general education diploma (GED).

Among the peculiarities of the North American educational system is the fact that during all basic education, parents have the opportunity to choose home schooling for their children. Teaching their own children at home, parents can receive many resources that include state government guidelines, and even state funds. Parents or guardians then can become the student's tutor. No formal training is 
required for the parent teacher, and many states even provide financial incentives from the government to aid the costs. Home schooling first became legal in 1993 in the US (SCHUMM, 1998) and is a favorite of conservative religious families who prefer that their children not attend public schools, and who may lack the financial resources to send their children to private schools.

College placement exams are not required in the US as they are in Brazil. In order to enter institutions of higher education, students are evaluated in many different aspects. Grades and school records are used as part of their application for admission to university and/or college. In addition, there is a grade point average (GPA) on a scale of 0 to 4.0 for each student that is an important factor for admission. GPA is understood as a measure of academic performance.

School grades in the US are usually represented through an alphabetical scale rather than numerically, for example, from the highest academic success (A) to failure (F) in sequence: A, A-, B, B-, C, C-, D and F. This alphabetical scale can be converted to numerical values during classes in order to have a more precise evaluation (Table 1).

Table 1 - An example of how grades can be converted to numerical values in a college class (Biology 121 at Onondaga Community College), showing total percentage, letter grade from the highest (A) to the lowest grade $(F)$, and quality of work

\begin{tabular}{l|l|l}
\hline \multicolumn{1}{c|}{ Total percentage } & \multicolumn{1}{|c}{ Letter grade } & \multicolumn{1}{c}{ Quality of work } \\
\hline $95-100 \%$ & A & Superior \\
$90-94 \%$ & A- & Excellent \\
$80-89 \%$ & B- to B+ & Good \\
$65-79 \%$ & C- to C+ & Fair \\
$55-64 \%$ & D- to D+ & Poor \\
$\leq 54 \%$ & F & Unacceptable \\
\hline
\end{tabular}

Source: Bodah, E.T. Biology 121 Class. Onondaga Community College: Syracuse, NY, USA. May, 2017.

For admission to higher education institutions, consideration is also placed on which educational institutions the student graduated from, letters of recommendation, and voluntary extra-curricular activities during his or her basic education.

There are traditional schools that are recognized nationally and internationally by the quality of their educational practices, and therefore can contribute to a better classification of their students. A student who has attended a prestigious school may have an advantage over another student, especially if they have the same grades and GPA. The way universities interpret their GPA can also be diffe- 
rent. This is because two schools may have different evaluation standards, such as requiring a foreign language or extra-curricular activities (COLEMAN; HOFFER, 1987), while others may not.

In addition, admission requirements for each university and college also greatly vary according to the state to which they belong, as mentioned in the beginning of this article. To overcome possible obstacles, there are counselors and/or academic advisors in each institution who can meet each student individually. These professionals can be seen even before the official acceptance at the university and continue through graduation, as needed. Most schools mandate a certain level of council with these professionals on a regular basis while earning an undergraduate degree.

The academic year in US schools usually begins in August or September of one year, and continues through May or June of the following year. The school year can be composed of semesters or quarters. There are school breaks throughout the year, but the largest vacation is during the summer months of June, July, and August. However, students may choose to take summer classes or conduct internship during these months as opposed to taking the time off.

\section{Academic levels in higher education}

The first academic level that US students can earn a degree is the associate degree. Associate degrees are broadly accepted and usually take two years to complete, with basic and introductory courses. There are two types of associate degrees: associate of arts (AA) in the field of human, administrative, and social sciences; and associate of science (AS) in a scientific or applied field.

Courses taken in order to get an AA or an AS can be transferred to a four-year institution, and used toward a higher undergraduate (college) degree, such as a four-year degree. Among the introductory courses that students can take, there are classes in literature, biological, exact or social sciences, arts, and history. The purpose of pursuing an associate degree is to have advantage over competitors at the job market. AA and AS degrees provide general knowledge in the student's area of interest as well as an academic foundation that prepares the student for success at a four-year college or university.

To earn an associate degree, many students enroll in community colleges, which are very common in the US Most of these students will transfer these credits to complete an undergraduate four-year (baccalaureate or bachelors) degree. However, some of these students already consider their education complete with an AA or AS. 
Students can use the credits from a community college while transferring to four-year colleges or universities (having already completed the first two years of their four-year degree) in order to complete a four-year degree in only two additional years. One particular feature of the US higher education system is that some degrees, such as medical school, veterinary medicine, law, and pharmacy are considered professional degrees. These degrees require the applicant to hold a four-year degree before even applying for admission for the professional degree. Dentistry in the US is considered an area of training in medical studies, and dentists must complete courses as rigorous as medical school, all after having obtained a four-year bachelors degree prior.

In theory, US degrees are designed to develop critical thinking, classroom participation, engagement through laboratory practices, and community service. Classes range from lectures, with tens to hundreds of students, to small groups and discussion seminars, with relatively few students. The atmosphere in the university classroom is usually dynamic. Students should share their opinion, argue their point of view, participate in discussions, and conduct presentations. The amount of homework assignments can be exhaustive, while other courses have little to none.

Generally, lesson plans or syllabi are well defined ahead of time, and should involve the following parts: (i) lecture or theoretical class, and (ii) fieldwork or practical class. Most instructors assign weekly readings, homework, and other tasks hoping that the students will prepare in advance to understand the lectures. Continuous assessment though exams (first, mid-term, and final) are a large portion of the final course grade. If a student fails a course following the final exam, some instructors might offer extra credit activities. However, there is never an obligation for the instructor to offer a second chance to recover grades.

Upon continuation of post-secondary education, students may choose between a bachelor of science (BS) degree, and a bachelor of arts (BA) degree. A bachelor degree or baccalaureate is an undergraduate academic degree awarded by colleges and universities upon completion of a course of study lasting three to seven years (depending on institution and academic discipline). Therefore, BS and BA degrees are a step up from AS and AA degrees.

A BA generally requires a minimum of 180 class hours per quarter, of which at least 18 hours are advanced level of research. BAs are generally awarded on the fields of languages, literature, history, and other areas of humanities. A BS generally involves technical areas, requiring a minimum of 180 classroom hours per quarter, of which at least 27 hours are at the advanced level of research. BSs are usually awarded in the areas of physical and biological sciences, engineering 
and agriculture. After choosing a BA or a BS, students can still change their area of study during their undergraduate studies (STUDYUSA, 2016)

After a BA or BS, students can go to graduate school. Graduate degrees can be completed at either the masters level or the doctorate level. There is no formal equivalent in the US to the so-called specialization courses, which are often available at Brazilian universities. However, students can take classes and earn certificates.

To enroll in graduate school, pre-admission tests are required, and they vary depending on the area of study. Some of the most popular tests required by US universities are: the graduate record examination (GRE) for scientific areas and engineering, the Law School Admission Test (LSAT) for law school, the Graduate Management Admission Test (GMAT) in the field of mathematics, and the Medical College Admissions Test (MCAT) for admission to medical school.

Foreign students who do not have English as their native language must also submit scores for the Test of English as a Foreign Language (TOEFL). These tests are offered throughout the year at several US and Canadian institutions. However, the TOEFL can be taken in different cities world-wide. In addition to test scores, students also need writing samples, and letters of reference in order to be considered for admission to graduate school.

Masters programs can be either professional or scientific programs, and usually take one to two years to complete. These programs can be concluded by thesis defense or by conducting a research project and submitting a final report. For instance, a masters in business administration (MBA) can take two years to be completed, while a masters degree in a specific area such journalism can be completed in just one year. Many students may consider pursuing a masters degree as the first step towards a doctorate. Similar to bachelors degrees, masters degrees are typically offered as masters of science (MS) or masters of arts (MA); however, some are highly specialized such as the aforementioned MBA.

Doctoral degrees can be professional such as medical doctorate of medicine (MD), doctor of veterinary medicine (DVM), and doctor of pharmacy (Pharm. D.). In addition, doctorates can also be doctorate in education (Ed.D.), and doctorate of philosophy (Ph.D). To obtain a doctorate degree, courses vary from three to six years, depending on the field of study.

Generally, in the first part of a doctoral program, students take mandatory and elective graduate level courses, as well as, graduate seminars. The rest of the time is dedicated to conducting research, and writing a doctoral dissertation. For most $\mathrm{Ph} . \mathrm{D}$. degrees, there is a qualifying examination with written and oral tests 
that officially recognize students as doctoral candidates, and a final examination in addition to the defense of the dissertation.

\section{Federal Regulations for Higher Education}

The US federal government has a post-secondary education platform that offers some guidelines to higher education institutions (USDE, 2016). Some legislative milestones that are available on this platform are the following: changes to the higher education law of 1965, and the Higher Education Opportunity Act (HEOA) of 2008. The HEOA authorizes the establishment of new undergraduate programs, covers ramifications for college costs, accreditation, student financial aid, disclosures and compliance provisions, student loan "sunshine" provisions, teacher professional development and international education. Other policies can also be based on this act such as: opportunities for Hispanic Americans; masters programs in universities and colleges with a historically black clientele; and master's programs in predominantly black institutions.

A variety of higher education institutions can be found in the US such as community colleges, religious organizations, strictly private universities, private universities with public funding, and public universities. Private colleges and universities are independent of the government and generally do not receive public funding. The enrollment rate may be higher in universities and private colleges because they are smaller and are linked to other entities. One example of such organization is the University of Seattle, which is part of the Jesuit education network.

Public universities are part and parcel of their state or even local governments. Each of the 50 US states operates at least one state university and possibly several state colleges. Many of these public universities have the name of the state, or the word "state" in their names, such as Washington State University and the University of Washington. Although they belong to the state, public universities are not tuition exempt. Therefore, the cost of education is the responsibility of each student. Public universities consistently have the lowest tuition rates when compared to private institutions in the US

According to the USDE (2016) during the 2013-14 school year, expenditures with annual tuition for undergraduate study, excluding fees and housing, were estimated to be at $\$ 15,640$ for public institutions. The cost was even higher at private universities, totaling $\$ 40,614$ for private non-profit institutions, and $\$ 23,135$ for private institutions. In fact, this cost in public universities may still exceed $\$ 40,000$. Students often apply for scholarships, student loans, or grants in order 
to pay for tuition. Some students might work two to three different jobs while in school.

As there is not a Ministry of Education with functions equivalent to those of the MEC in Brazil, an important reference for US institutions of higher education is the Carnegie classification. In this classificatory system institutions are placed in teaching rankings according to their functions and courses offered. In 2005, the Carnegie Foundation undertook a thorough review of the classificatory system and introduced a multiple classification method. The change was in part to mitigate the quantitative placement and partly to assess the classification in a qualitative and integrated way.

According to Zhao (2011), institutional changes aiming to obtain a higher ranking reveal that institutions have increasingly abandoned their original mission, aiming only at a better "position on the scale" and, therefore, enhance their credibility. The new parameters of the Carnegie classification are organized around the following items: (i) undergraduate educational program; (ii) postgraduate educational program; (iii) enrollment; (iv) university profile; (v) size and educational context.

Even at a high cost, the US higher education system is very popular and attracts many students from around the world. Competitive rankings coupled with high-end research to increase fundraising has helped position US colleges and universities become among the world's most prestigious colleges and universities.

Haynie (2014) states that during the 2013-14 school year, a total of 886,052 undergraduate and graduate students were admitted to colleges and universities in the US At the time, foreign students accounted for about four percent of college students in the country. In addition to seeking internal support bodies in formal educational institutions, there is also a variety of non-profit associations that promote professional development in higher education, offering assistance services to these international students.

According to the StudyUSA report (2016), the major non-formal institutions that contribute to higher education in this area are the following: American Education Council (ACE), the American Association of University Secretaries and Admissions Officials (AACRAO); American Association of State Colleges and Universities (AASCU); American Association of Community Colleges (AACC); National Association for University Admissions (NACAC); Association of International Educators (NAFSA); National Association of Professional Graduate Admissions (NAGAP); and the Association for Counseling for University Admissions Abroad (OACAC). 
In addition to these institutions, the USDE also has the EducationUSA, a network with more than 400 student centers in 170 countries. This network promotes higher education in the US to students around the world by providing accurate, complete and up-to-date information on US school opportunities. EducationUSA also provides services to help institutional leaders meet their recruitment demands and internationalization goals. Generally, centers are located in US embassies and consulates, Fulbright commissions, binational centers, universities and non-profit organizations.

Consulting is also a very popular approach for higher education success in the US For instance, many community colleges have been advised by the Achieving the Dream proposal, which is a comprehensive non-governmental reform movement for student success. Together with a network of higher education institutions, coaches and advisors, state policy teams, investors and partners, they are helping more than 4 million community college students achieve better economic opportunities.

\section{Washington State as a model}

In order to illustrate how management of higher education functions, Washington State will be used as an example of public administration. It is worth remembering that, although the US education system is being sought by students worldwide, there are still many disparities in the teaching-learning processes. According to the research and education data center, in Washington State alone, of the 62,810 students who graduated from state public schools in 2009 , only 20,774 went to a community college or technical program, and even less 18,763 went to a four-year university (USDE, 2016).

In addition, degree completion rates for the students who are admitted to college also vary. About $68.8 \%$ of university students in Washington complete a degree within six years. Nationally, this number drops to $57.4 \%$. For students in community colleges and technical schools, the completion rate is higher, at around $74 \%$. Of these students, $41 \%$ will transfer or complete an associate's degree.

The WA Legislative Assembly created the Washington Student Achievement Council (WSAC) in July 2012. By its statute, the Council provides strategic planning, supervision, advocacy and support programs aimed at academic success in higher education in Washington State (WASHINGTON STATE LEGISLATURE, 2016). On their webpage, information on strategic planning, control and defense reads as follows: 
- Strategic planning, oversight, and advocacy: propose goals and recommend resources to increase educational attainment by means of a ten-year Roadmap and a short-term Strategic Action Plan; propose improvements and innovations needed to address the state's evolving educational needs; advocate for higher education and educate the public on the economic, social, and civic benefits of postsecondary education; connect and align the work of educational programs, schools, and institutions to support student transitions from secondary and postsecondary education to the workforce; facilitate analysis and research to increase educational attainment and system development; assess the need for additional degrees and programs throughout the state; improve student success by setting minimum college admission standards and by supporting students' transitions through all phases of education; protect education consumers by authorizing out-of-state institutions to operate in Washington and by monitoring program quality and finances; promote and safeguard quality education and training programs for veterans; represent the broad public interest above the interests of the individual institutions of higher education.

- Program administration: ensure the quality of state financial aid progra$\mathrm{ms}$ and services that support educational access and affordability; provide college savings opportunities through the Guaranteed Education Tuition (GET) program; prepare underrepresented middle and high school students for postsecondary education through early outreach and success programs such as College Bound and GEAR UP.

- Partnerships (per RCW 28B.77, the Student Achievement Council closely collaborates with the following agencies and organizations): Four-Year Institutions (Council of Presidents); independent Colleges of Washington; Office of Superintendent of Public Instruction; State Board for Community and Technical Colleges; Workforce Training and Education Coordinating Board; Washington State Board of Education; and Washington STEM.

- Public universities that make up the council are: the University of Washington, the University of Washington Bothell, the University of Washington Tacoma, Washington State University, Washington State University Tri-Cities, Washington State University Vancouver, Washington State University Spokane, Central Washington University, Western Washington University, Eastern Washington University, and the Evergreen State College. 


\section{Internal management at each higher education institution}

So far, through this paper we observed that there is a great amount of diversity, limited governmental inputs and a broad focus on the preparation for the job market contextualizing the higher educational system in the US Therefore, internal management makes a significant difference. Each institution can establish a participatory and inclusive council to meet local needs. Although the internal organization and structure of higher education institutions vary according to the size and mission of each institution, there are some common management strategies, such as university councils.

University councils are groups composed of academic community members and are prevalent in the US higher education institutions. Counselors are responsible for deliberating on academic management to ensure monitoring of the financial situation, defining strategies aiming to fulfilling institutional mission, and evaluating institutional and presidential.

Council size and structure, as well as the appointment of councilors vary according to the purpose of the institution. For instance, board members of some private non-profit institutions may exceed 50 people. Public institutions tend to have fewer advisors, which are usually appointed by the state government with approval of the legislative.

In some states, and in many community colleges, board members are chosen through general elections. For private institutions, the council can determine the criteria for selecting its members. The term of office of directors varies from four to 12 years. The boards can also hire and delegate much of the administrative responsibility to a president or chancellor.

The president is responsible for the institution's leadership role, managing its finances and budget, developing and executing the institution's strategic plan, as well as establishing accountability systems and performance appraisals. However, most of the president's work is outside of the institution, seeking financial and political support from the legislative and from the external public. Other functions that may involve the president are as follows: attending meetings with alumni and prospective students, and strengthening relationships with businesses and the community at large.

In addition to the president, other administrators play a leading role in various sectors. According to Eckel and King (2007), the typical North American framework for governance includes: (i) academic affairs, responsible for academic programs and research; (ii) student affairs, including student supervision and orientation services; (iii) business and administration, responsible for financial 
operations, ancillary services and campus facilities; and (iv) development, which is focused on fundraising and relationships with alumni.

Within each sector, there is also a variety of directors and department heads to complete the administrative structure. While presidents have primary responsibility for the institution, most presidents depend on a system of shared governance, the Senate, composed by faculty, administrators, and sometimes students in order to make institutional decisions.

The Senate is responsible for recommending and approving academic policies, such as those affecting new curricula and course proposals, reviewing requirements for obtaining an academic degree and for hiring university positions. Senate members typically include full-time and part-time professors, students, managers, employees, and sometimes members of the wider community. Generally, in large institutions, the senators are elected representing each of the institution departments and programs. Elections for faculty members and students may take place in different ways, according to the internal regulations of each group.

\section{Diversity at the University of Washington}

The University of Washington (UW) fits well into the management system described earlier, in addition to have a special focus on diversity due to its multicultural clientele. For instance, the UW homepage shows that community members should educate each other, formally and informally, in and out of the classroom, teaching each other to see the world from varied perspectives.

The UW further requires that all undergraduate students earn a minimum of three credits related to topics on diversity, which will have to be approved by the department or faculty member chosen by students. The institution considers diversity in different levels such as sociocultural, political, and economic, as well as ways that represent the human experience at local, regional or global levels. This coursework requirement is intended to help students develop an understanding of the complexities of life in increasingly diverse and interconnected communities.

Courses covering this topic may be associated with studies of races, ethnicities, classes, sex and gender, sexual orientation, nationality, ability and special needs, religion, creed, age and socioeconomic level. The activities of each course should encourage students to think critically about issues such as empowerment, inequality, marginalization, and social movements, as well as supporting effective intercultural communication skills.

This initiative builds on UNESCO's statements on diversity. According to the World Declaration on Education for All proposed in 1990, universal access to 
education for all must be guaranteed in order to promote equity and inclusion (UNESCO, 2016). Inclusion provides opportunities for students with disabilities, with different levels of learning, and with multicultural diversity. The purpose is to ensure that all students have access to knowledge, skills, and information that will prepare them to contribute to their communities and workplaces.

Currently, there are six areas listed as priorities in the UW statute covering the topic of diversity in the internal management process aimed at stimulating: (i) leadership and commitment; (ii) recruitment and retention; (iii) enrichment of learning and preparation for global citizenship; (iv) faculty and staff; (v) diversity research; and (vi) environment for diversity. Within each area there are specialized committees composed of administrators, faculty members, and students to make decisions at the local level.

\section{Conclusion}

The US higher education system is one of the most prestigious worldwide and attracts a great number of international students. Public management in higher education in the US is decentralized and, therefore, the federal government has limited influence over the decisions made within institutions.

In the absence of a federal regulatory ministry such as the MEC in Brazil, ranking and accreditation systems such as the Carnegie system become very important as an indicator of quality. Among the unique aspects of the US higher education is the university council composed by different members of the academic community.

Councilors may hire a president or chancellor who, along with the other university administrative sectors, represented by a senate, can make recommendations, implement actions and carry out public participatory management. Some institutions use academic committees to work on topics of social relevance, such as the diversity committee at the UW to increase inclusion and respect for the cultural diversity of its constituencies.

Despite the complexity of higher education management in the United States, each university or college has to work very hard to keep up with competition and high accreditation standards, regardless of their size. 


\section{References}

COLEMAN, James S.; HOFFER, Thomas. Public and private high schools: the impact of communities. New York: Basic Books, 1987.

ECKEL, Peter D.; KING, Jacqueline. United States. In: INTERNATIONAL handbook of higher education. Netherlands: Springer, 2007. p. 1035-1053.

HAYNIE, Devon. Number of International College Students Continues to Climb. US News, 2014. Available at: <http://www.usnews.com/education/best-colleges/articles/2014/11/17/number-of-international-college-students-continues-to-climb>. Viewed: 24 June 2016.

SCHUMM, Walter. R. Trends in homeschooling in a Midwestern community. Psychological Reports, Penn State Schuylkill, USA, V. 82, n. 2, p. 364-366, 1998.

STUDYUSA. Available at: <https://www.studyusa.com/en/a/58/understanding-the-american-education-system>. Viewed: 20 June 2016.

UNESCO. Education for all. Available at: <http://www.unesco.org/new/pt/brasilia/education/ education-for-all/>. Viewed: 9 Sept. 2016

UNITED STATE DEPARTMENT OF EDUCATION. National Center for Education Statistics. Digest of Education Statistics, 2014 (NCES 2016-006), 3.

WASHINGTON STATE LEGISLATURE. Available at: <http://apps.leg.wa.gov/rcw>.Viewed: 20 June 2016.

ZHAO, Chun-Mei. As classificações: uma breve introdução. Revista Ensino Superior Unicamp, Campinas, p. 72-80, 2011. Available at: <https://www.revistaensinosuperior.gr.unicamp.br/artigos/as-classificacoes-carnegie-uma-breve-introducao>. Viewed: 23 June 2016. 